\title{
Kinerja Campuran Aspal Porus yang Dimodifikasi dengan Lateks
}

\author{
(Asphalt Porous Mixture Performance Modified with Latex)
}

ANITA RAHMAWATI, RIDWAN NUR HIDAYAT

\begin{abstract}
ABSTRAK
Aspal merupakan bahan yang digunakan sebagai perekat pada perkerasan lentur. Pada umumnya perkerasan lentur melimpaskan air hujan hanya dipermukaan perkerasan saja, akibatnya sering terjadi genangan yang membahayakan pengendara yang melintas. Salah satu alternatif untuk mengatasi permasalahan ini adalah dengan menggunakan teknologi aspal porus. Aspal porus merupakan perkerasan aspal dengan rongga be rkisar $11 \%-28 \%$ sehingga bisa mencegah genangan air saat terjadi hujan. Penelitian ini mengkaji pengaruh lateks sebagai bahan pengganti sebagian aspal pada perkerasan aspal porus dengan variasi kadar lateks $0 \%, 1 \%, 3 \%, 5 \%$ dan 7\%. Spesifikasi yang digunakan adalah spesifikasi AAPA (1997). Nilai KAO didapat sebesar $5,75 \%$, pada pengujian aspal dengan campuran lateks didapat nilai penetrasi tertinggi adalah 63,9, kehilangan berat minyak 0,2576, nilai daktalitas, titik lembek mengalami kenaikan seiring penambahan kadar lateks. Pada pengujian aspal porus dengan variasi kadar lateks diapat nilai density dan VFA mengalami penurunan seiring bertambahnya kadar lateks, nilai VMA, flow dan VIM cenderung mengalami peningkatan seiring bertambahnya kadar lateks, nilai stabilitas marshall tertinggi 592,04 kg, nilai Marshall Quotient 132,76 kg/mm, nilai Asphalt Flow Down 0,21\% dan nilai Cantabro Loss adalah 14,61\%.
\end{abstract}

Kata kunci: Asphalt porous, lateks, karakteristik Marshall.

\section{ABSTRACT}

Asphalt is a material used as an adhesive on flexible pavements. In general, flexible pavements run off rainwater only on the pavement surface, resulting in frequent puddles that endanger passing motorists. One alternative to overcome this problem is to use porous asphalt technology. Porous asphalt is an asphalt pavement with void ratio from $11 \%-28 \%$ so that it can prevent stagnant water when it rains. This study examines the effect of latex as a partial substitute for asphalt on porous asphalt pavements with latex content variations of 0\%, 1\%, 3\%, 5\% and 7\%. The specifications used are the AAPA (1997) specifications. OAC value was obtained at $5.75 \%$, in testing the asphalt with a mixture of latex, the highest penetration value was 63.9, oil weight loss was 0.2576, the ductility value, the softening point increased with the addition of latex content. In testing porous asphalt with variations in latex content, the value of density and VFA decreased with increasing levels of latex, VMA, flow and VIM values tended to increase with increasing latex content, the highest marshall stability value was $592.04 \mathrm{~kg}$, the marshall quotient value was $132.76 \mathrm{~kg} / \mathrm{mm}$, the asphalt flow down value was $0.21 \%$ and the cantabro loss value was $14.61 \%$.

Keywords: Asphalt porous, latex, Marshall characteristics. 


\section{Pendahuluan}

Indonesia merupakan negara dengan iklim tropis basah dan intensitas hujan yang tinggi. Hal ini akan sangat berpengaruh terhadap ketahanan perkerasan jalan di Indonesia karena dengan semakin meningkatnya volume kendaraan tiap tahunnya dan dengan curah hujan yang tinggi peluang kerusakan perkerasan jalan akan semakin besar.

Teknologi aspal porus dinilai dapat mengatasi permasalahan di atas, hal ini karena air akan meresap ke dalam lapisan pondasi atas secara vertikal dan horizontal. Aspal porus merupakan generasi baru dalam perkerasan lentur, sifat porus diperoleh karena campuran ini menggunakan agregat halus lebih sedikit dibanding campuran biasa sehingga memiliki kandungan rongga/pori lebih besar yang diharapkan memiliki kekesatan yang tinggi dan pori dapat berfungsi sebagai saluran drainase di dalam campuran (Amiruddin dkk., 2018). Lapisan aspal porus ini secara efektif dapat memberikan tingkat keselamatan yang lebih, terutama di waktu hujan agar tidak terjadi aquaplaning sehingga menghasilkan kekesatan permukaan yang lebih kasar, dan dapat mengurangi kebisingan (noise reduction). Perkerasan aspal porus memiliki dua fungsi, yaitu sebagai praktek pengelolaan limpasan air hujan dan untuk mendukung beban lalu lintas (Padilha dkk., 2018). Namun penggunaan agregat halus yang lebih sedikit mengakibatkan menurunnya kemampuan bahan pengikat untuk mempertahankan posisi agregat, maka dibutuhkan aspal dengan daya ikat yang kuat, awet dan berviskositas tinggi. Salah satu contoh aspal yang dimodifikasi dengan aspal alam yaitu lateks (karet alam cair). Lateks adalah istilah yang digunakan untuk menyebut getah dari pohon karet. Getah alam diperoleh dari tanaman Hevea brasiliensis, kemudian diolah dan diperdagangkan sebagai bahan industri berupa Rubber Smoked Sheet (RSS), getah pekat, crumb rubber, dan lain-lain (Suaryana dan Sofyan, 2019). Pencampuran lateks pada perkerasan jalan raya diharapkan dapat meningkatkan kekuatan aspal pada saat menahan beban kendaraan.

Penelitian mengenai penambahan lateks pada campuran beraspal sudah dilakukan oleh Thanaya dkk. (2015) dengan penambahan variasi lateks $0 \%, 2 \%, 4 \%, 6 \%, 8 \%$, dan $10 \%$ terhadap total perekat pada campuran aspal beton lapis aus (AC-WC) dengan aspal penetrasi 60/70. Diperoleh kesimpulan bahwa penambahan lateks ke dalam campuran AC-WC menunjukkan nilai stabilitas Marshall yang semakin baik, nilai flow semakin tinggi, Marshall Quotient semakin baik, nilai VIM yang semakin rendah, nilai VMA yang semakin rendah serta nilai VFA yang semakin tinggi.

Penelitian ini mengkaji pengaruh lateks sebagai bahan pengganti sebagian aspal pada campuran aspal porus dengan variasi kadar lateks. Spesifikasi yang digunakan yakni Australian Asphalt Pavement Association (1997) yang selanjutnya disingkat menjadi AAPA (1997). Perbedaan penelitian ini dengan penelitian sebelumnya adalah penggunaan aspal porus dengan campuran lateks sebagai pengganti sebagian aspal dengan variasi kadar lateks, sedangkan penelitian sebelumnya yang dilakukan Nursandah dan Zaenuri (2019) menggunakan aspal beton lapis aus (AC-WC) dengan penambahan variasi kadar lateks.

\section{METODE PENELITIAN}

\section{Tahapan Penelitian}

Penelitain ini dilakukan dengan beberapa tahapan diantaranya persiapan alat dan bahan, pengujian bahan, perencanaan campuran, pembuatan dan pengujian benda uji dan analisis data. 
TABel 1. Batas Gradasi Agregat Campuran Aspal Porous

\begin{tabular}{|c|c|c|c|c|}
\hline \multirow{2}{*}{ No. } & \multicolumn{2}{|c|}{ Ukuran Saringan } & \multicolumn{2}{|c|}{ Spesifikasi Lolos Saringan (\%) } \\
\hline & $\mathbf{m m}$ & & Batas & Nilai Tengah \\
\hline 1. & 19,1 & $3 / 4$ & 100 & 100 \\
\hline 2. & 12,7 & $1 / 2$ & $85-100$ & 92,5 \\
\hline 3. & 9,52 & $3 / 8$ & $45-75$ & 60 \\
\hline 4. & 4,75 & No. 4 & $10-25$ & 17,5 \\
\hline 5. & 2,36 & No. 8 & $7-15$ & 11 \\
\hline 6. & 1,18 & No. 16 & $6-12$ & 9 \\
\hline 7. & 0,6 & No. 30 & $5-12$ & 8,5 \\
\hline 8. & 0,3 & No. 50 & $4-8$ & 6 \\
\hline 9. & 0,15 & No. 100 & 3-7 & 5 \\
\hline 10. & 0,075 & No. 200 & $2-5$ & 3,5 \\
\hline 11. & & & $4,5-6$ & \\
\hline
\end{tabular}

Sumber: (AAPA, 1997)

Penelitian ini dilakukan di Laboratorium Transportasi dan Jalan Raya, Program Studi Teknik Sipil, Fakultas Teknik, Universitas Muhammadiyah Yogyakarta. Bahan lateks berupa lateks cair dan aspal yang digunakan adalah aspal penetrasi 60/70. Dalam campuran aspal porus digunakan campuran bergradasi terbuka (open graded) yang mengacu kepada AAPA (1997) dalam (Ghulam dkk., 2017). Batas gradasi agregat campuran aspal porus dapat dilihat pada Tabel 1.

\section{Pengujian Bahan}

Sebelum bahan-bahan material digunakan pada campuran perkerasan dilakukan pengujian sifatsifat fisis bahan sebagai berikut :

(i) Agregat adalah salah satu komponen utama pada perkerasan jalan yang menentukan daya dukung, mutu, kualitas dan keawetan suatu perkerasan. Maka dari itu diperlukan pengujian terhadap bahan agregat. Pengujian agregat yang dilakukan adalah pengujian berat jenis, penyerapan agregat dan keausan agregat pada agregat kasar. Sedangkan untuk agregat halus pengujian yang dilakukan yakni pengujian berat jenis dan penyerapan agregat.

(ii) Aspal adalah salah satu komponen penting dalam perkerasan aspal itu sendiri, sehingga kualitas aspal harus diperhatikan agar sesuai dengan ketentuan. Pengujian yang dilakukan yaitu pengujian berat jenis aspal, penetrasi aspal, daktalitas, titik lembek dan kehilangan berat minyak.

\section{Pembuatan Benda Uji}

Benda uji dibuat dengan campuran aspal panas dengan variasi kadar aspal untuk mencari KAO dan variasi kadar lateks pada KAO, campuran aspal yang telah tercampur rata dimasukkan ke dalam cetakan benda uji, lalu ditumbuk menggunakan alat pemadatan (compactor) sebanyak $2 \times 50$ tumbukan.

Jumlah benda uji dibuat pada masing-masing pengujiannya disesuaikan pada kebutuhan penelitian, yakni benda uji untuk menentukan KAO dan benda uji untuk penelitian. jumlah benda uji yang dibuat dapat dilihat pada Tabel 2 dan Tabel 3. 
A. Rahmawati E R.N. Hidayat/Semesta Teknika, Vol. 24, No. 1, 47-61

TABEL 2. Jumlah Benda Uji Untuk Mencari KAO

\begin{tabular}{cccc}
\hline Variasi Kadar & \multicolumn{3}{c}{ Jumlah Benda Uji } \\
\cline { 2 - 4 } Aspal & Marshall & AFD & Cantabro Loss \\
\hline $4,5 \%$ & 2 & 2 & 2 \\
$5 \%$ & 2 & 2 & 2 \\
$5,5 \%$ & 2 & 2 & 2 \\
$6 \%$ & 2 & 2 & 2 \\
Jumlah & 8 & 8 & 8 \\
\hline
\end{tabular}

TABEL 3. Jumlah Benda Uji Dengan Campuran Lateks Pada KAO

\begin{tabular}{cccc}
\hline Variasi Kadar & \multicolumn{3}{c}{ Jumlah Benda Uji } \\
\cline { 2 - 4 } Lateks & Marshall & $\boldsymbol{A F D}$ & Cantabro Loss \\
\hline $0 \%$ & 2 & 2 & 2 \\
$1 \%$ & 2 & 2 & 2 \\
$3 \%$ & 2 & 2 & 2 \\
$5 \%$ & 2 & 2 & 2 \\
$7 \%$ & 10 & 2 & 2 \\
Jumlah & 2 & 10 & 10 \\
\hline
\end{tabular}

\section{Mencari Kadar Aspal Optimum (KAO)}

Menentukan kadar aspal optimum dilakukan dengan menggunakan grafik pita dan parameter dari AAPA (1997). Spesifikasi ini hanya menentukan beberapa parameter saja pada karakteristik marshall yang diantaranya VIM, stabilitas marshall, flow dan MQ. Ditambah 2 parameter lainnya yakni AFD dan CL. Seperti yang telah diketahui bahwa aspal porus memiliki rongga yang lebih banyak daripada perkerasan jalan pada umumnya, hal ini sejalan dengan pernyataan Ma dkk, (2020) bahwa aspal porus umumnya memiliki nilai VIM lebih dari $18 \%$ bahkan hingga $23 \%$ atau $25 \%$ untuk mengatasi masalah drainasi. Spesifikasi AAPA (1997) dapat dilihat pada Tabel 4 berikut.

TABEL 4. Spesifiasi Aspal Porous

\begin{tabular}{lc}
\hline \multicolumn{1}{c}{ Kriteria Perencanaan } & Nilai \\
\hline Cantabro loss $(\%)$ & Maks. 20 \\
Asphalt flow down $(\%)$ & Maks. 0,3 \\
Stabilitas marshall $(\mathrm{kg})$ & Min. 500 \\
Kelelehan plastis $(\mathrm{mm})$ & $2-6$ \\
Kadar rongga udara $(\%)$ & $10-28$ \\
Kekakuan marshall $(\mathrm{kg} / \mathrm{mm})$ & Maks. 400 \\
\hline
\end{tabular}


Kadar aspal optimum ditentukan dengan pengujian benda uji pada kadar aspal yang memenuhi semua parameter pada spesifikasi AAPA (1997).

\section{Uji Marshall}

Pengujian marshall dilakukan untuk menentukan karakteristik marshall yang diantaranya adalah sebagai berikut :

\section{Density}

Nilai density menunjukkan nilai kepadatan suatu campuran beraspal. Semakin tinggi nilai density maka semakin baik kerapatan campuran tersebut. Nilai density dapat dihitung dengan persamaan berikut ;

$\mathrm{g}=\mathrm{c} / \mathrm{f}$

Dengan, g adalah density (gr/cc), c adalah berat kering (gram) dan $\mathrm{f}$ adalah hasil pengurangan antara berat dalam keadaan kering jenuh permukaan dan berat dalam air.

\section{Void Filled with Asphalt (VFA)}

VFA atau rongga terisi aspal adalah persen rongga yang terdapat diantara partikel agregat (VMA) yang terisi oleh aspal, tidak termasuk aspal yang diserap oleh agregat. Nilai VFA dapat dihitung dengan persamaan berikut :

$\mathrm{VFA}=100 \times(\mathrm{VMA}-\mathrm{VIM}) / \mathrm{VMA}$

Dengan, VMA adalah rongga udara pada mineral agregat $(\%)$ dan VIM adalah rongga udara pada campuran setelah pemadatan $(\%)$.

\section{Void in Mixture Asphalt (VMA)}

VMA Rongga antar agregat (VMA) adalah ruang rongga diantara partikel agregat pada suatu perkerasan, termasuk rongga udara dan volume aspal efektif (tidak termasuk volume aspal yang diserap agregat). Nilai VMA dapat dihitung dengan persamaan berikut :

$\mathrm{VMA}=100-((\mathrm{Gmb} \times \mathrm{Ps}) / \mathrm{Gsb})$

Dengan, Gmb adalah berat jenis curah campuran padat $(\mathrm{gr} / \mathrm{cc})$, Ps adalah persen agregat terhadap berat total campuran $(\%)$ dan Gsb adalah berat jenis curah agregat (gr/cc).

\section{Void In the Mixture (VIM)}

VIM adalah volume rongga yang masih tersisa setelah campuran beton aspal dipadatkan. Nilai VIM dapat dihitung dengan persamaan berikut :

VIM=100×((Gmm-Gmb)/Gmm)

Dengan, Gmm adalah berat jenis maksimum campuran $(\mathrm{gr} / \mathrm{cc})$ dan $\mathrm{Gmb}$ adalah berat jenis curah campuran padat $(\mathrm{gr} / \mathrm{cc})$.

\section{Stabilitas}

Nilai stabilitas diperoleh dari nilai yang ditunjukkan oleh jarum dial pada alat uji. Nilai yang ditunjukkan pada jarum dial perlu dikonversikan terhadap alat Marshall (Arifin dkk., 2018). Nilai stabilitas bisa dihitung dengan persamaan berikut :

$\mathrm{s}=\mathrm{p} . \mathrm{q} \cdot \mathrm{r}$

Dengan, $\mathrm{s}$ adalah stabilitas $(\mathrm{kg}), \mathrm{p}$ adalah pembacaan jarum dial, $\mathrm{q}$ adalah kalibrasi alat marshall dan $r$ adalah angka koreksi benda uji.

\section{Flow}

Flow adalah besarnya deformasi vertikal sampel yang terjadi mulai saat awal pembebanan sampai kondisi kestabilan maksimum sehingga sampel hancur. Seperti halnya cara memperoleh nilai stabilitas, nilai flow merupakan nilai dari masing-masing yang ditunjukkan oleh jarum dial.

\section{Marshall quotient $(M Q)$}

Kekakuan marshall merupakan hasil bagi stabilitas dengan kelelehan dengan satuan $\mathrm{kg} / \mathrm{mm}$. Semakin tinggi nilai MQ, maka kemungkinan akan semakin tinggi kekakuan suatu campuran dan semakin rentan campuran tersebut terhadap keretakan. Nilai MQ dapat dihitung dengan persamaan berikut:

Marshall quotient=stabilitas/flow

Pengujian marshall diawali dengan menimbang benda uji dalam keadaan kering, kemudian benda uji direndam dalam air selama 24 jam dan benda uji ditimbang dalam air. Setelah itu benda uji ditimbang dalam keadaan jenuh kering permukaan, kemudian benda uji direndam dalam water bath dengan suhu $60^{\circ} \mathrm{C}$ 
selama 30 menit, kemudian benda uji dipasang ke mesin pengujian Marshall.

\section{Uji Asphalt Flow Down}

Asphalt Flow Down (AFD) menunjukkan kadar aspal maksimum yang tercampur homogen dengan agregat tanpa terjadinya pemisahan aspal (Fauziah dan Wijayati, 2016). Prosedur pengujiannya yaitu dengan menimbang campuran aspal dalam nampan yang telah dilapisi alumunium foil, lalu campuran aspal dalam nampan tersebut dimasukkan ke dalam oven dengan suhu $\pm 160^{\circ} \mathrm{c}$ selama \pm 60 menit, selanjutnya campuran aspal dan nampan tersebut dituangkan secara cepat sehingga yang tersisa pada nampan adalah sisa dari campuran aspal, lalu nampan dan sisa campuran aspal tersebut ditimbang.

\section{Uji Cantabro Loss}

Pengujian ini bertujuan untuk mengetahui persentase kemampuan campuran terhadap pelepasan butir dengan menggunakan mesin abrasi Los Angeles sebanyak 300 putaran (Ismayalomi, Rahardjo, dan Pranoto, 2019). Prosedur pengujian dilakukan dengan menimbang dan mencatat berat awal benda uji, kemudian benda uji tersebut dimasukkan ke dalam mesin abrasi, lalu diputar sebanyak 300 kali tanpa bola besi, selanjutnya benda uji dikeluarkan dari mesin abrasi Los Angeles dan ditimbang beratnya.

\section{HASIL DAN PEMBAHASAN}

\section{Aspal dan Agregat}

Pengujian aspal dan agregat perlu dilakukan untuk mendukung penelitian agar sesuai dengan spesifikasi yang ditentukan oleh Bina Marga (2010). Pada penelitian ini, sifat fisis aspal yang diperiksa adalah berat jenis, penetrasi, daktalitas, titik lembek dan kehilangan berat minyak aspal. Pemeriksaan sifat fisis aspal ini dilakukan dalam 2 kondisi, yakni tanpa campuran lateks dan dengan variasi campuran lateks $1 \%, 3 \%, 5 \%$ dan $7 \%$. Hasil pengujian sifat fisis aspal dan aspal + variasi kadar lateks dapat dilihat pada Tabel 5 dan Tabel 6.

Pada Tabel 5 dapat dilihat bahwa hasil pengujian aspal telah memenuhi spesifikasi.

TABel 5. Hasil Pengujian Aspal

\begin{tabular}{ccc}
\hline Jenis Pengujian & Spesifikasi & Hasil \\
\hline Berat jenis & $\geq 1$ & 1,06 \\
Penetrasi $(0,1 \mathrm{~mm})$ & $60-70$ & 63,2 \\
Daktalitas $(\mathrm{cm})$ & $\geq 100$ & 153 \\
${\text { Titik lembek }\left({ }^{\circ} \mathrm{c}\right)}_{\text {Kehilangan berat minyak }(\mathrm{gr})}$ & $\geq 48$ & 51,5 \\
\hline
\end{tabular}

TABEl 6. Hasil Pengujian Aspal + Variasi Kadar Lateks (1\%, 3\%, 5\% dan 7\%)

\begin{tabular}{cccccc}
\hline Pengujian & Spek & \multicolumn{3}{c}{ Hasil } \\
\cline { 3 - 5 } & & $\mathbf{1 \%}$ & $\mathbf{3 \%}$ & $\mathbf{5 \%}$ & $\mathbf{7 \%}$ \\
\hline Berat jenis & $\geq 1$ & 1,0311 & 1,0349 & 1,0434 & 1,0560 \\
Penetrasi $(0,1 \mathrm{~mm})$ & $60-70$ & 63,9 & 47,3 & 58,2 & 49,4 \\
Daktalitas $(\mathrm{cm})$ & $\geq 100$ & 153 & 155,5 & 156 & 56 \\
Titik lembek $\left({ }^{\circ} \mathrm{c}\right)$ & $\geq 48$ & 50 & 55 & 55,5 & 0,376 \\
Kehilangan berat & $\leq 0,8$ & 0,0301 & 0,2576 & 0,0943 & \\
minyak (gr) & & & & \\
\hline
\end{tabular}


Pada pengujian aspal dengan variasi kadar lateks menunjukkan bahwa semakin tinggi prosentase kadar lateks yang digunakan, maka nilai penetrasi mempunyai kecenderungan semakin menurun. Hal ini disebabkan karena lateks pada kondisi suhu ruang akan mengeras, sehingga semakin banyaknya kadar lateks nilai penetrasi akan semakin turun, sampai pada kondisi dibawah yang disyaratkan terutama pada kadar 3\%, 5\% dan 7\%.

Pengujian berat jenis dilakukan pada agregat kasar maupun halus, hal ini dilakukan untuk mengetahui berat jenis curah kering, berat jenis jenuh kering permukaan, berat jenis semu dan penyerapan air. Selain itu dilakukan juga pengujian abrasi untuk agregat kasar yang bertujuan untuk mengetahui kekuataan dari agregat kasar. Hasil pengujian agregat kasar dan halus dapat dilihat pada Tabel 7 dan Tabel 8.
Pada Tabel 7 dan Tabel 8 dapat dilihat bahwa hasil pengujian agregat kasar dan agregat halus telah memenuhi spesifikasi.

\section{Kadar Aspal Optimum (KAO)}

Untuk menentukan kadar aspal optimum, benda uji dibuat dengan variasi kadar aspal dan dilakukan pengujian dengan spesifikasi AAPA (1997). Pengujian dengan kadar aspal yang memenuhi seluruh parameter spesifikasi AAPA (1997) ditentukan sebagai kadar aspal optimum.

Hasil dari pengujian benda uji dengan variasi kadar aspal untuk menentukan KAO dapat dilihat pada Tabel 9.

Untuk tiap detail hasil yang ada di Tabel 9 dapat dilihat pada Gambar 1 sampai Gambar 9.

TABel 7. Hasil Pengujian Agregat Kasar

\begin{tabular}{ccc}
\hline Jenis Pengujian & Spesifikasi & Hasil \\
\hline Berat jenis curah kering & & 2,58 \\
Berat jenis jenuh kering permukaan & $\geq 2,5$ & 2,64 \\
Berat jenis semu & & 2,74 \\
Penyerapan air (\%) & $<3$ & 2,36 \\
Keausan agregat (\%) & $<40$ & 28,38 \\
\hline
\end{tabular}

TABel 8. Hasil Pengujian Agregat Halus

\begin{tabular}{ccc}
\hline Jenis Pengujian & Spesifikasi & Hasil \\
\hline Berat jenis curah kering & & 2,55 \\
Berat jenis jenuh kering permukaan & $\geq 2,5$ & 2,63 \\
Berat jenis semu & & 2,95 \\
Penyerapan air (\%) & $<3$ & 2,36 \\
\hline
\end{tabular}


A. Rahmawati E R.N. Hidayat/Semesta Teknika, Vol. 24, No. 1, 47-61

TABEl 9. Hasil Pengujian Parameter Aspal Porus Dengan Variasi Kadar Aspal Untuk Menentukan KAO

\begin{tabular}{lccccc}
\hline \multirow{2}{*}{$\begin{array}{l}\text { Karakteristik } \\
\text { Campuran }\end{array}$} & Spek. & \multicolumn{5}{c}{ Kadar Aspal (\%) } \\
\cline { 3 - 6 } & & $\mathbf{4 , 5}$ & $\mathbf{5}$ & $\mathbf{5 , 5}$ & $\mathbf{6}$ \\
\hline$C L(\%)$ & $\leq 20$ & 24,78 & 10,94 & 13,20 & 9,42 \\
AFD $(\%)$ & $\leq .0,3$ & 0,04 & 0,13 & 0,17 & 0,26 \\
Stabilitas $(\mathrm{kg})$ & $\geq 500$ & 529,72 & 482,98 & 592,04 & 545,30 \\
Flow $(\mathrm{mm})$ & $2-6$ & 5,50 & 4,70 & 3,61 & 3,40 \\
$V I M(\%)$ & $10-28$ & 11,49 & 11,70 & 11,17 & 11,21 \\
$M Q(\mathrm{~kg} / \mathrm{mm})$ & $\leq 400$ & 96,31 & 102,76 & 164,00 & 160,38 \\
& Kadar Aspal Optimum (KAO) & & & & $\mathbf{5 , 7 5}$ \\
\end{tabular}

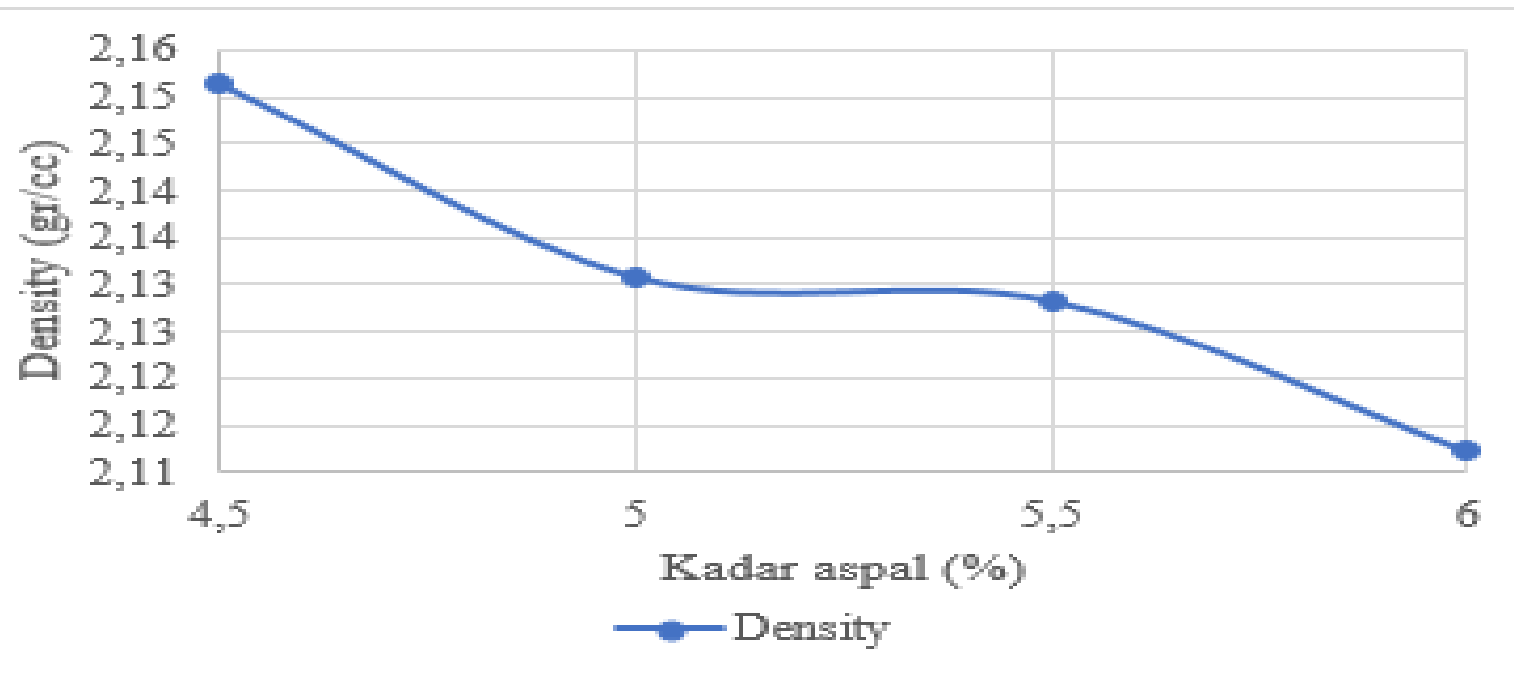

GAMbar 1. Grafik Hubungan Antara Kadar Aspal dan Density

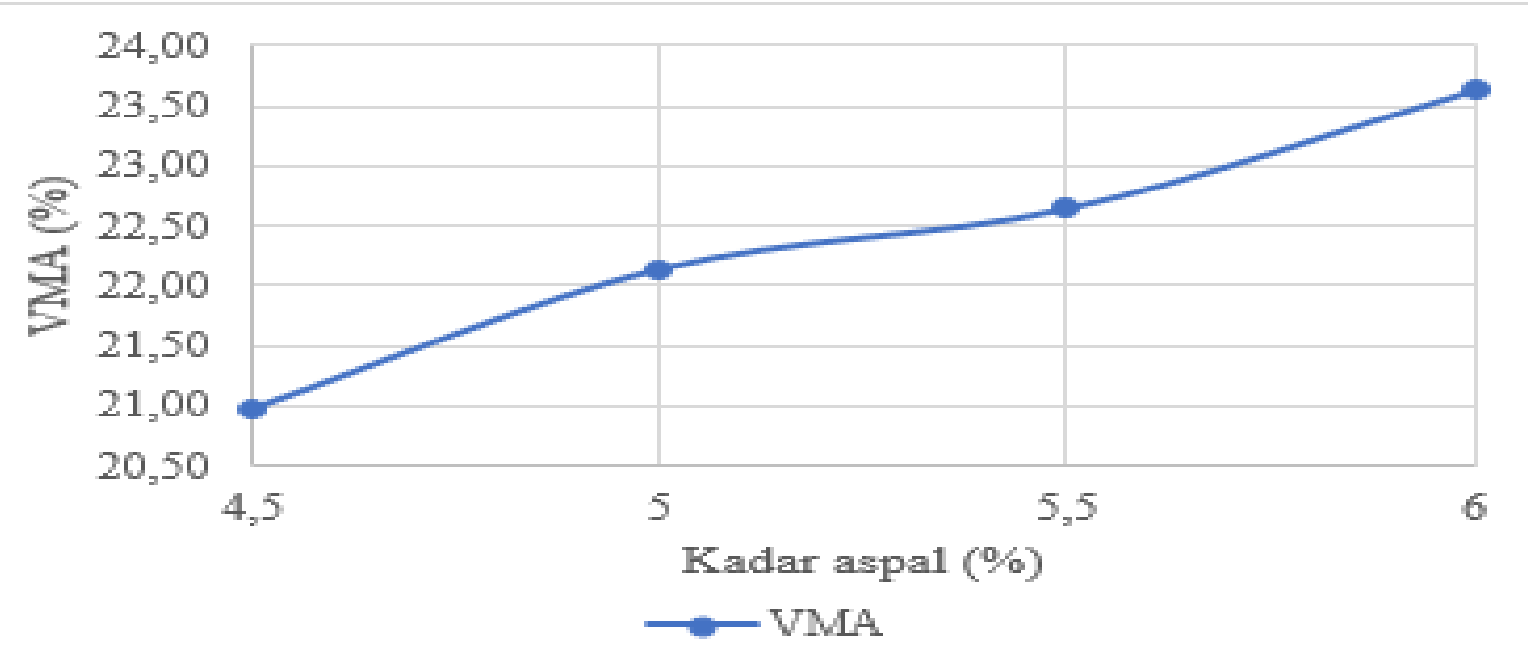

GAMBAR 2. Grafik Hubungan Antara Kadar Aspal dan VMA 
Pada Gambar 1 dapat dilihat bahwa nilai density mengalami penurunan seiring bertambahnya kadar aspal. Hal ini sejalan dengan penelitian Fauziah dan Wijayati (2016) pada penelitiannya mengenai pengaruh kadar limbah kaca sebagai substitusi agregat halus terhadap karakteristik campuran aspal porus, dimana nilai density menurun seiring bertambahnya kadar aspal. Penurunan density ini disebabkan karena semakin banyaknya kadar aspal yang digunakan dengan proses pemadatan yang kurang sempurna mengakibatkan rongga semakin besar dan kepadatannya menurun.
Pada Gambar 2 dapat dilihat bahwa nilai VMA meningkat seiring bertambahnya kadar aspal. Hal ini terkait dengan nilai density yang dihasilkan. Nilai density yang rendah disebabkan karena besarnya rongga antar agregat, sehingga dengan bertambahnya kadar aspal membuat VMA naik, hal ini menyebabkan nilai density turun. Hal ini sejalan dengan penelitian Fauziah dan Wijayati (2016) dalam menentukan KAO pada penelitiannya, dimana nilai VMA meningkat seiring bertambahnya kadar aspal.

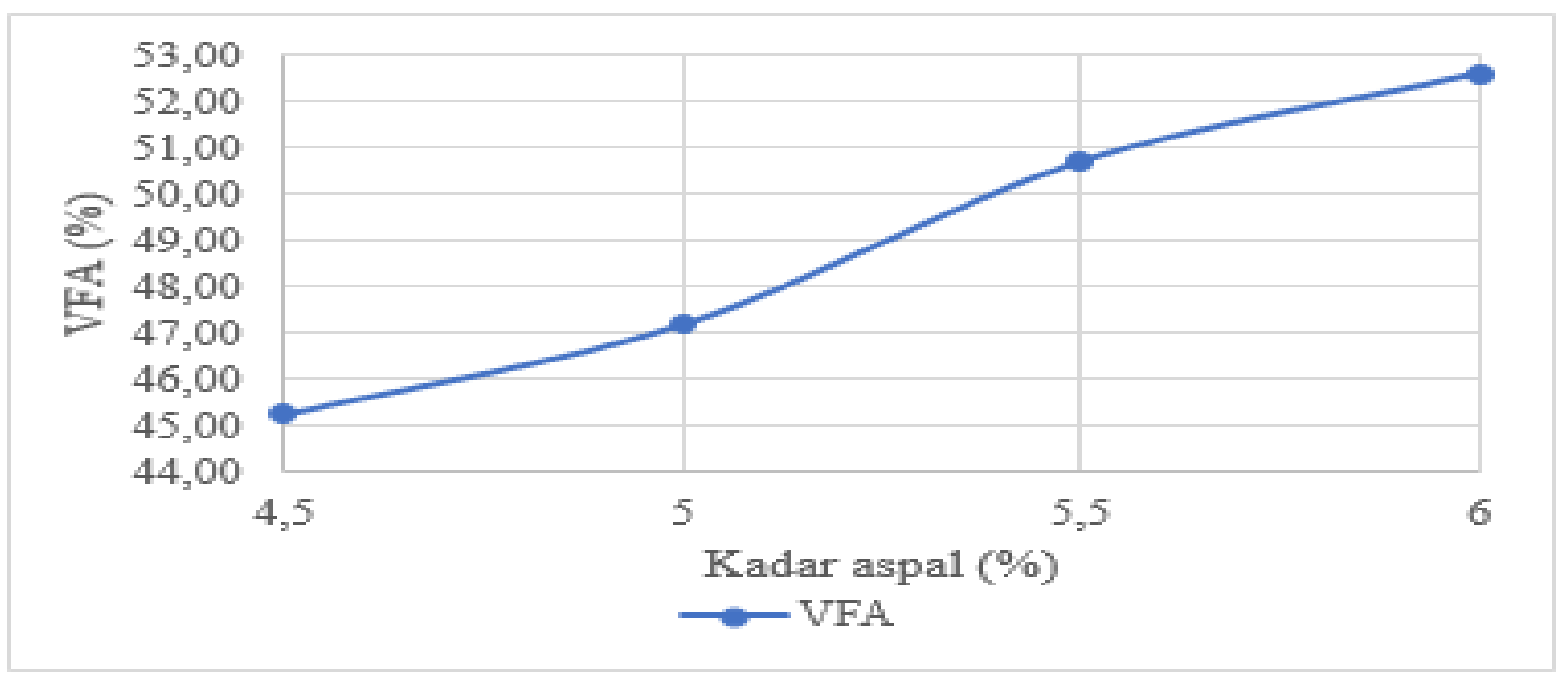

GAmbar 3. Grafik Hubungan Antara Kadar Aspal dan VFA

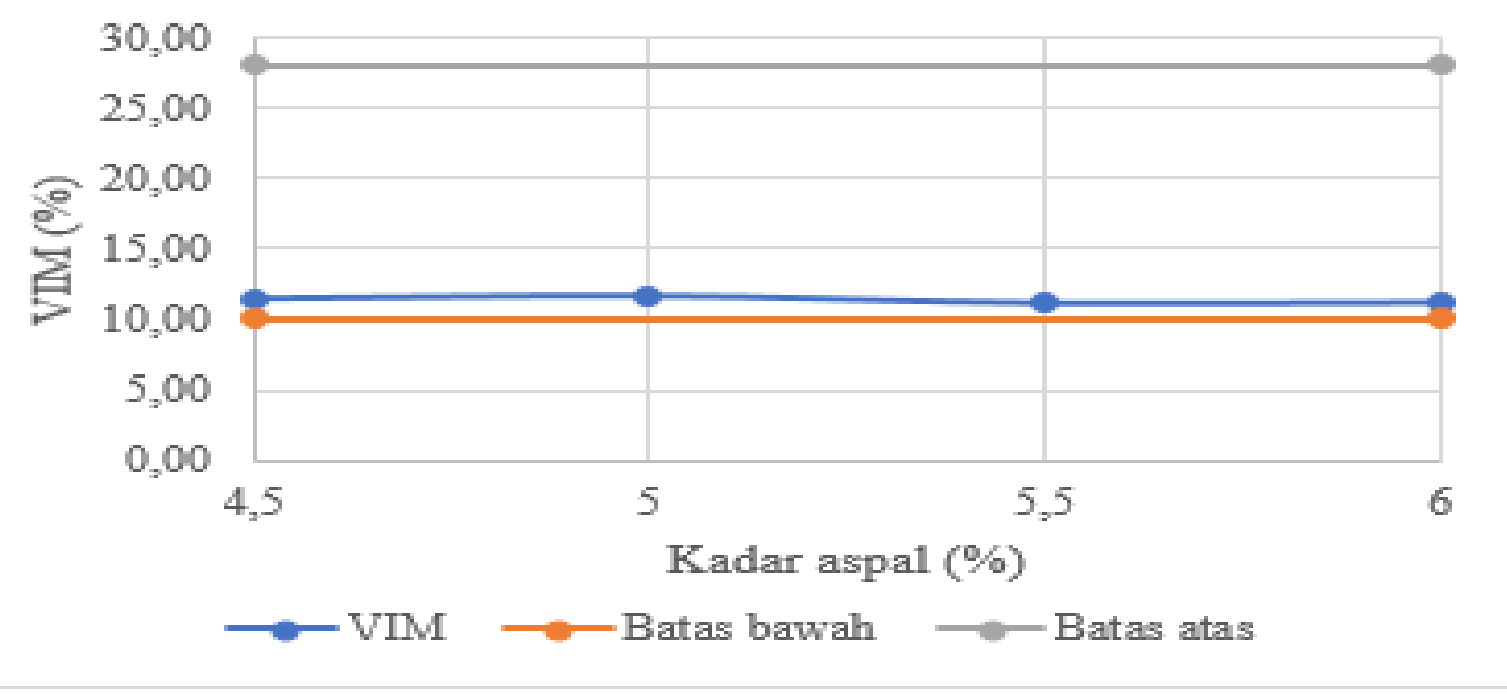

GAMBAR 4. Grafik Hubungan Antara Kadar Aspal dan VIM 
Pada Gambar 3 dapat dilihat bahwa nilai VFA meningkat seiring bertambahnya kadar aspal hal ini karena dengan semakin bertambahnya kadar aspal yang digunakan akan mengisi rongga yang ada. Tetapi dengan pemadatan yang kurang sempurna rongga yang ada akan tetap besar walau aspal yang digunakan semakin banyak terutama pada campuran aspal porous.

Pada Gambar 4 dapat dilihat bahwa nilai VIM kecenderungannya mengalami peningkatan, hal ini disebabkan karena pemadatan yang kurang sempurna sehingga dengan peningkatan aspal yang digunakan tidak bisa mengisi rongga dalam campuran.
Pada Gambar 5 dapat dilihat bahwa nilai stabilitas marshall mengalami kecenderungan mengalami penurunan, hal ini disebabkan karena menurunnya nilai kepadatan yang mengakibatkan kemampuan campuran menerima beban semakin menurun.

Pada Gambar 6 dapat dilihat nilai flow mengalami penurunan seiring bertambahnya kadar aspal, hal ini disebebakan karena aspal yang digunakan tidak bisa mengisi ronggarongga yang ada dengan sempurna, sehingga nilai flow menjadi semakin menurun dengan bertambahnya kadar aspal.

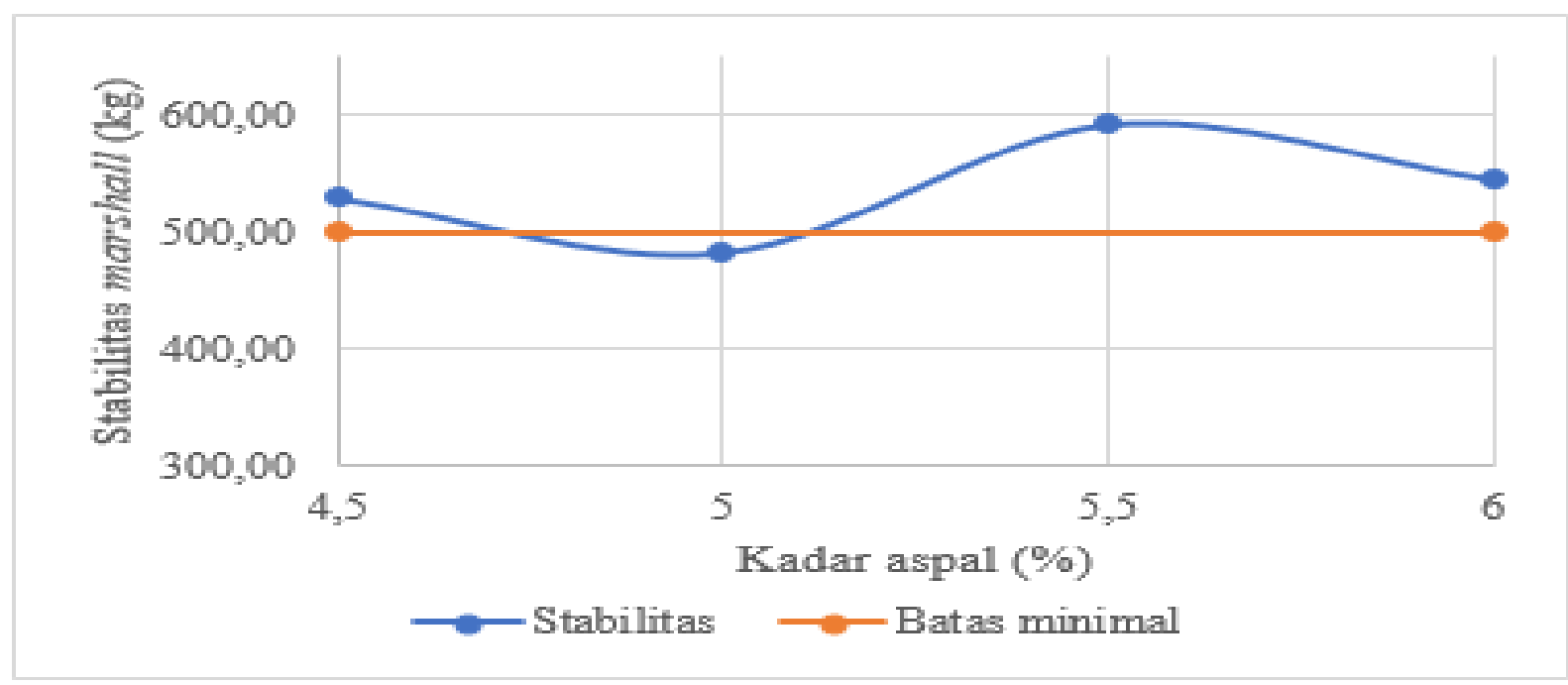

Gambar 5. Grafik Hubungan Antara Kadar Aspal dan Stabilitas

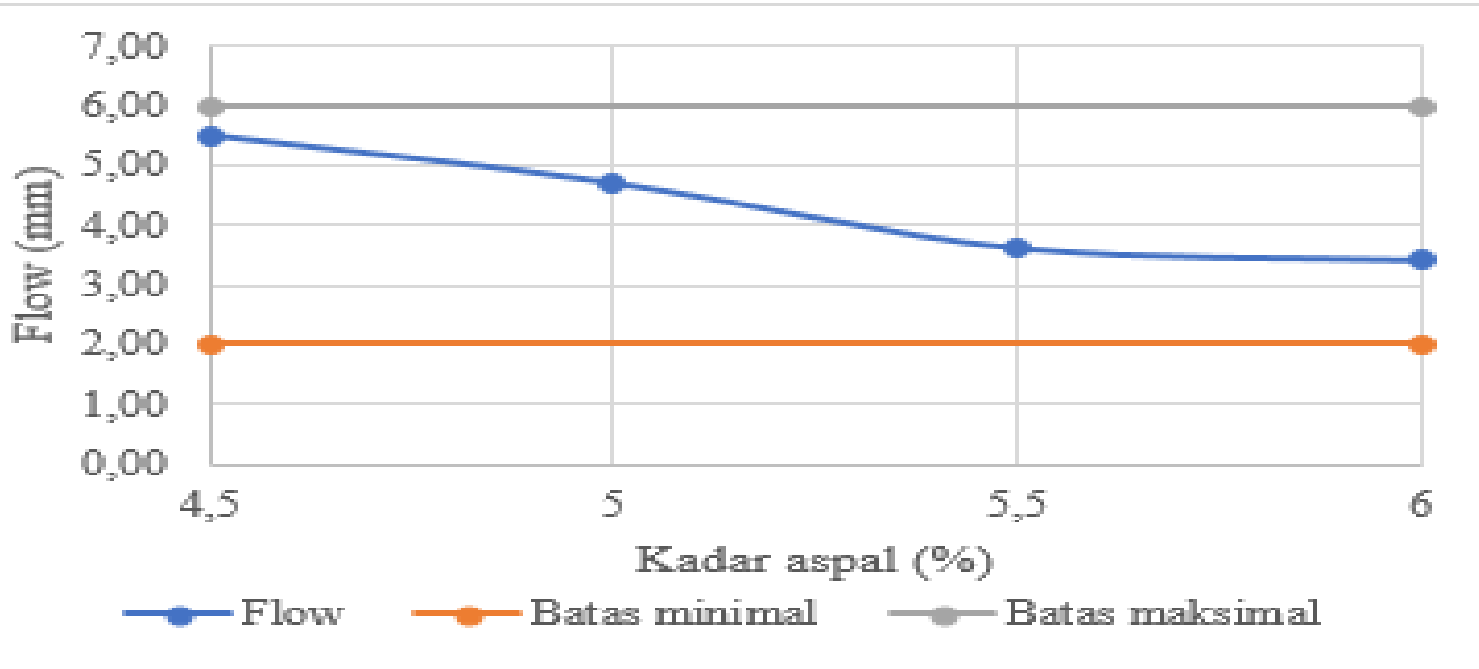

GAmBAR 6. Grafik Hubungan Antara Kadar Aspal dan Flow 
Pada Gambar 7 dapat dilihat bahwa nilai AFD mengalami peningkatan seiring bertambahnya kadar aspal, hal ini karena dengan semakin banyaknya aspal yang digunakan maka daya ikat aspal terhadap agregat akan semakin besar. Hal ini sejalan dengan penelitian Fauziah dan Wijayati (2016) dalam menentukan KAO pada penelitiannya, dimana nilai AFD meningkat seiring bertambahnya kadar aspal pada campuran aspal porus.

Pada Gambar 8 dapat dilihat bahwa nilai CL mengalami kencederungan menurun dengan bertambahkan kadar aspal. Ini disebabkan karena semakin banyaknya aspal yang digunakan akan mengikat agregat semakin baik maka keausan dari campuran aspal porous akan menurun.

\section{Parameter Marshall, AFD dan CL Aspal Porus dengan Variasi Lateks pada KAO}

Hasil pengujian parameter marshall campuran aspal porus kondisi KAO dengan kadar lateks $0 \%, 1 \%, 3 \%, 5 \%$ dan $7 \%$ diperoleh nilai-nilai berupa density, VMA, VFA, VIM, stabilitas, flow dan MQ. Hasil pengujian parameter marshall, AFD dan CL aspal porus pada KAO dengan variasi kadar lateks dapat dilihat pada Tabel 10.

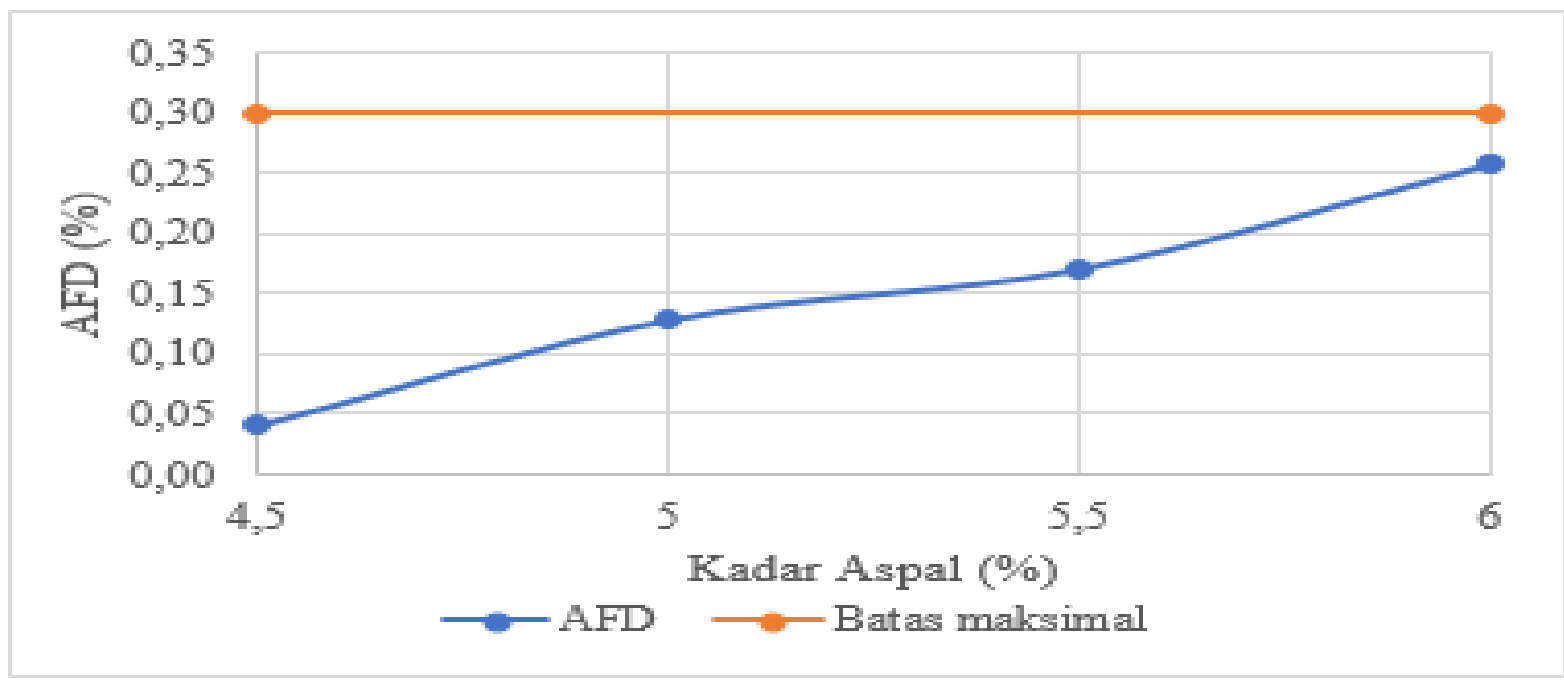

GAMBAR 7. Grafik Hubungan Antara Kadar Aspal dan AFD

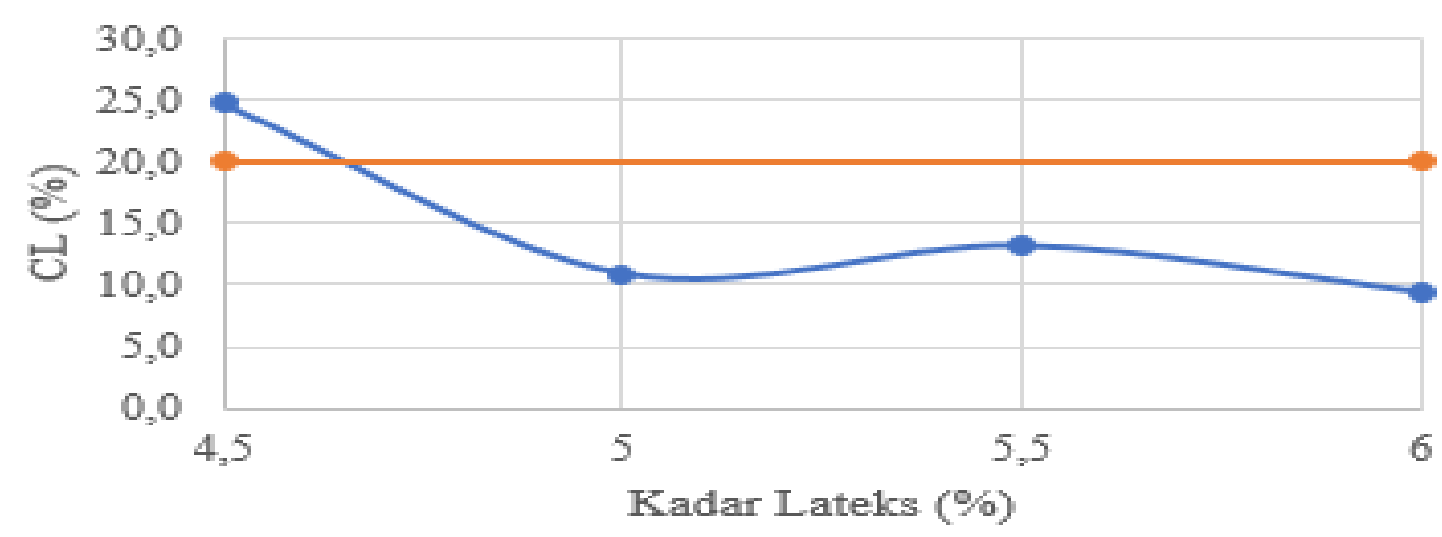

- Cantabro loss _ Batas maksimal

GAMBAR 8. Grafik Hubungan Antara Kadar Aspal dan CL 
A. Rahmawati E R.N. Hidayat/Semesta Teknika, Vol. 24, No. 1, 47-61

TABEl 10. Hasil Pengujian Karakteristik Aspal Porus Kondisi KAO Dengan Variasi Kadar Lateks

\begin{tabular}{|c|c|c|c|c|c|c|}
\hline $\begin{array}{c}\text { Kadar Lateks } \\
(\%)\end{array}$ & $\operatorname{VIM}(\%)$ & $\begin{array}{c}\text { Stabilitas } \\
\text { Marshall (kg) }\end{array}$ & $\begin{array}{l}\text { Flow } \\
(\mathrm{mm})\end{array}$ & $\begin{array}{c}M Q \\
(\mathrm{~kg} / \mathrm{mm})\end{array}$ & $A F D(\%)$ & $C L(\%)$ \\
\hline 0 & 11,69 & 638,78 & 4,90 & 136,02 & 0,23 & 14,54 \\
\hline 1 & 11,03 & 475,19 & 3,90 & 132,76 & 0,19 & 8,65 \\
\hline 3 & 11,70 & 498,56 & 5,40 & 92,36 & 0,18 & 10,99 \\
\hline 5 & 12,25 & 592,04 & 6,20 & 98,23 & 0,21 & 9,20 \\
\hline 7 & 12,60 & 537,51 & 5,30 & 106,60 & 0,16 & 14,61 \\
\hline Spesifikasi & $10-28$ & Min. 500 & $2-6$ & Maks. 400 & Maks. 0,3 & Maks. 20 \\
\hline
\end{tabular}

Detail dari parameter untuk menentukan KAO dengan variasi kadar lateks dijelaskan berikut.

Pada Gambar 9 dapat dilihat bahwa nilai VIM mempunyai kecenderungan meningkat dengan bertambahnya kadar lateks. Hal ini disebabkan karena aspal yang ditambah lateks akan semakin tinggi nilai viskositasnya yang membuat aspal tersebut mengalami kesulitan dalam mengisi rongga didalam campuran.
Pada Gambar 10 dapat dilihat bahwa nilai stabilitas mengalami penurunan pada kadar lateks $1 \%$, dan meningkat pada kadar lateks $3 \%$ dan 5\%, lalu menurun kembali pada kadar lateks $7 \%$. Hal ini sedikit berbeda dengan penelitian Nursandah dan Zaenuri (2019) dimana nilai stabilitas campuran AC-WC dengan penambahan variasi lateks $3 \%, 5 \%$, $7 \%$, 9\% dan $11 \%$ didapatkan hasil stabilitas yang terus meningkat hingga kadar lateks $9 \%$, lalu menurun pada kadar lateks $11 \%$.

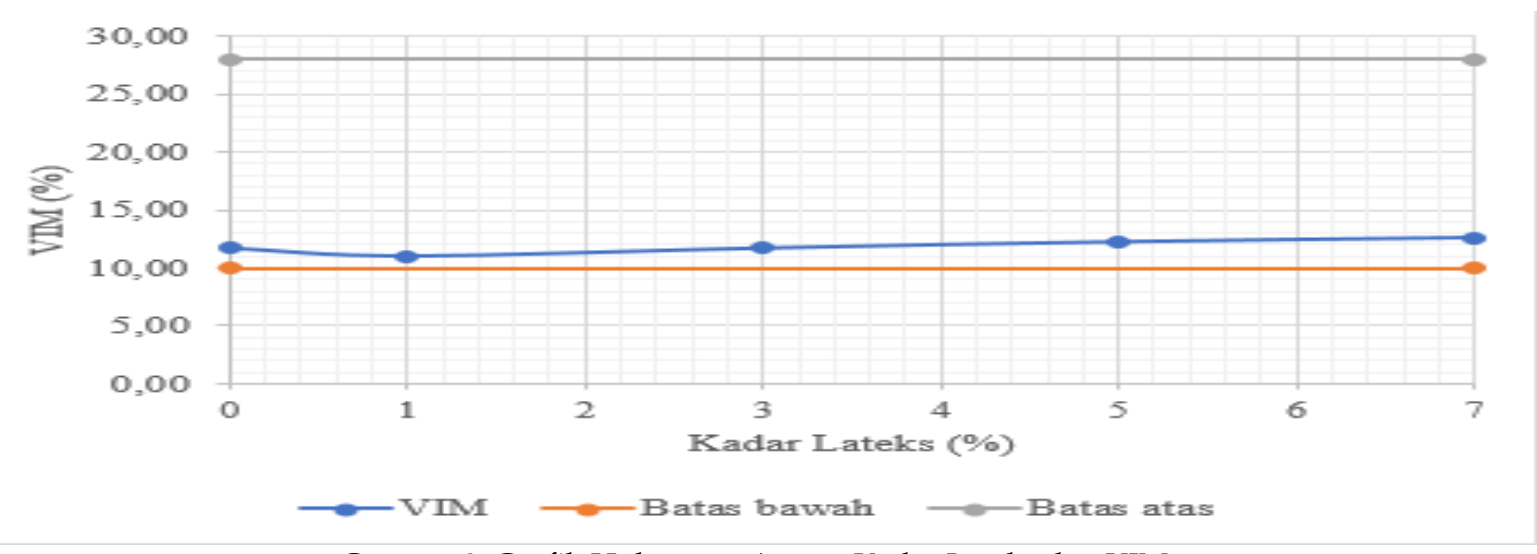

GAMBAR 9. Grafik Hubungan Antara Kadar Lateks dan VIM

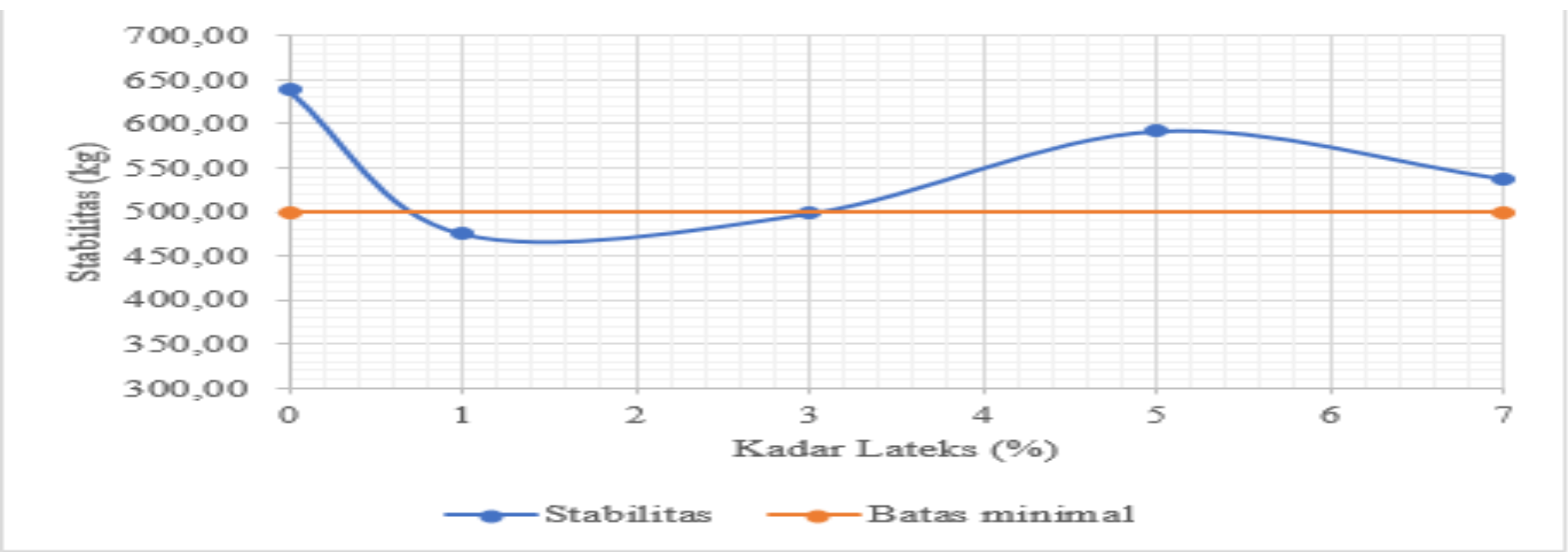

GAMBAR 10. Grafik Hubungan Antara Kadar Lateks dan Stabilitas 


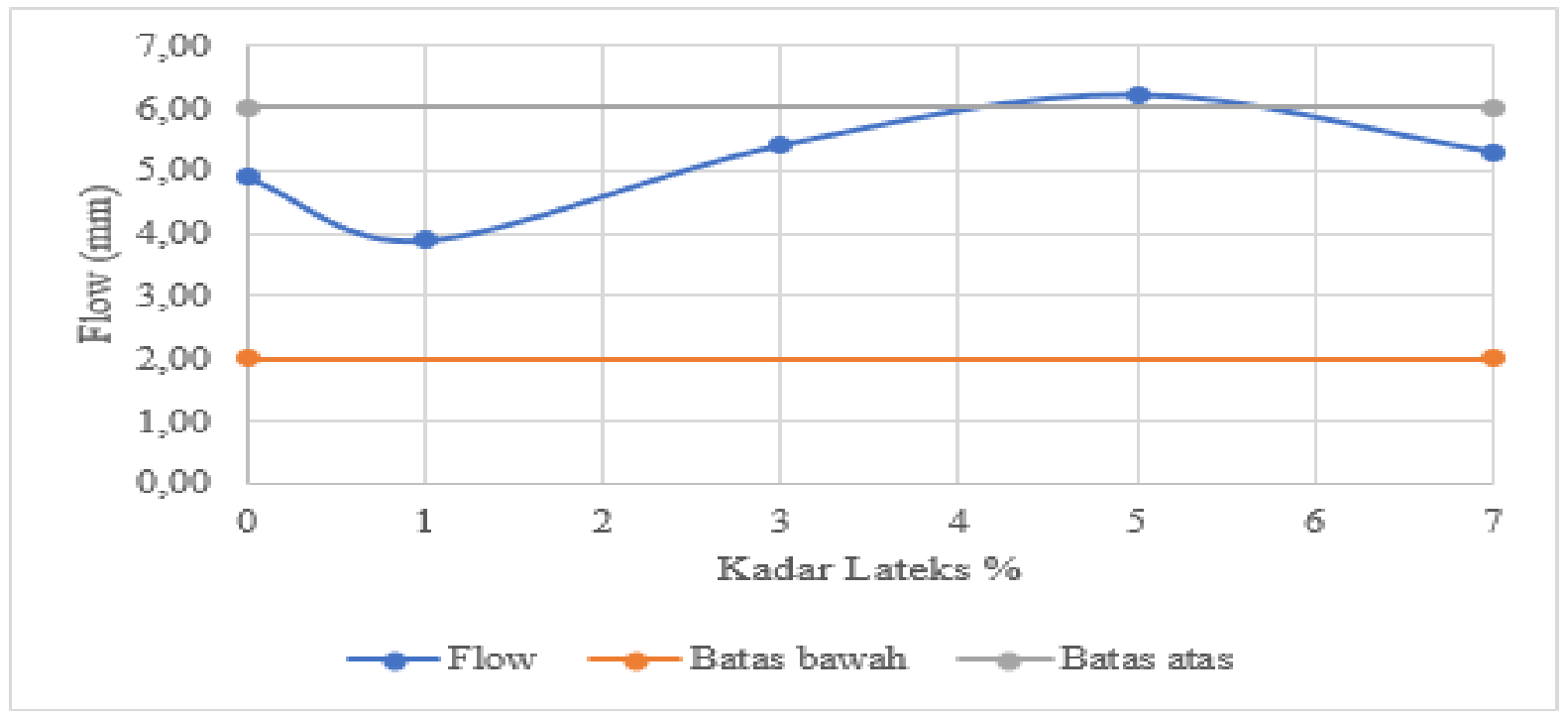

GAMBAR 11. Grafik Hubungan Antara Kadar Lateks dan Flow

Pada Gambar 11 dapat dilihat bahwa nilai flow mengalami peningkatan dengan bertambahnya kadar lateks. Hal ini sejalan dengan penelitian Nursandah dan Zaenuri (2019) dimana nilai flow campuran laston (AC-WC) dengan penambahan variasi lateks $3 \%, 5 \%, 7 \%, 9 \%$ dan $11 \%$ didapatkan hasil flow yang terus meningkat seiring bertambahnya kadar lateks hingga kadar lateks $11 \%$.
Pada Gambar 12 dapat dilihat bahwa nilai MQ mengalami penurunan dengan bertambahnya kadar lateks, hai ini terkait dengan hasil stabilitas dan flow yang didapatkan. Nilai MQ sejalan dengan penelitian Nursandah dan Zaenuri (2019) dimana nilai MQ campuran laston (AC-WC) dengan penambahan variasi lateks $3 \%, 5 \%, 7 \%, 9 \%$ dan $11 \%$ didapatkan hasil MQ yang meningkat pada pada kadar lateks $5 \%$ dan $7 \%$.

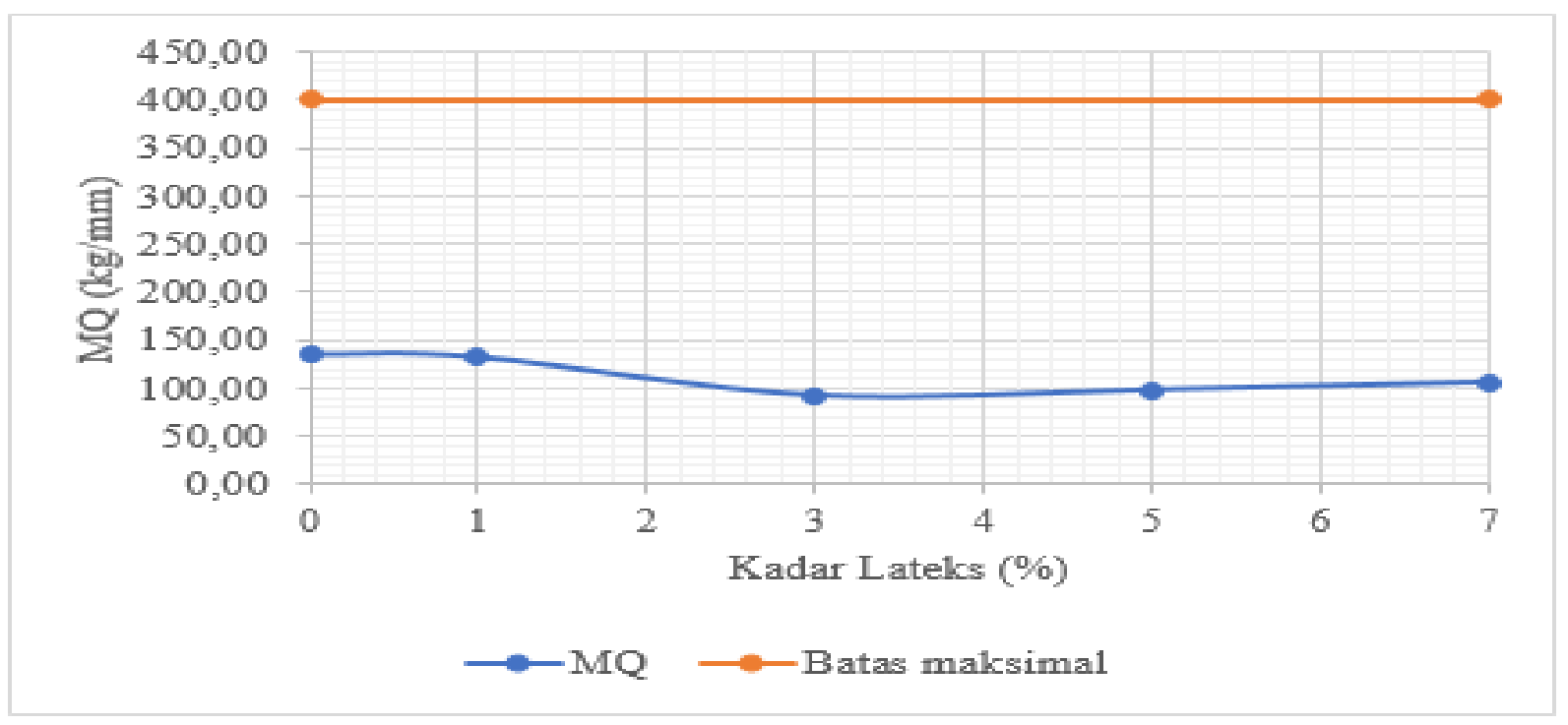

GAMBAR 12. Grafik Hubungan Antara Kadar Lateks dan MQ 


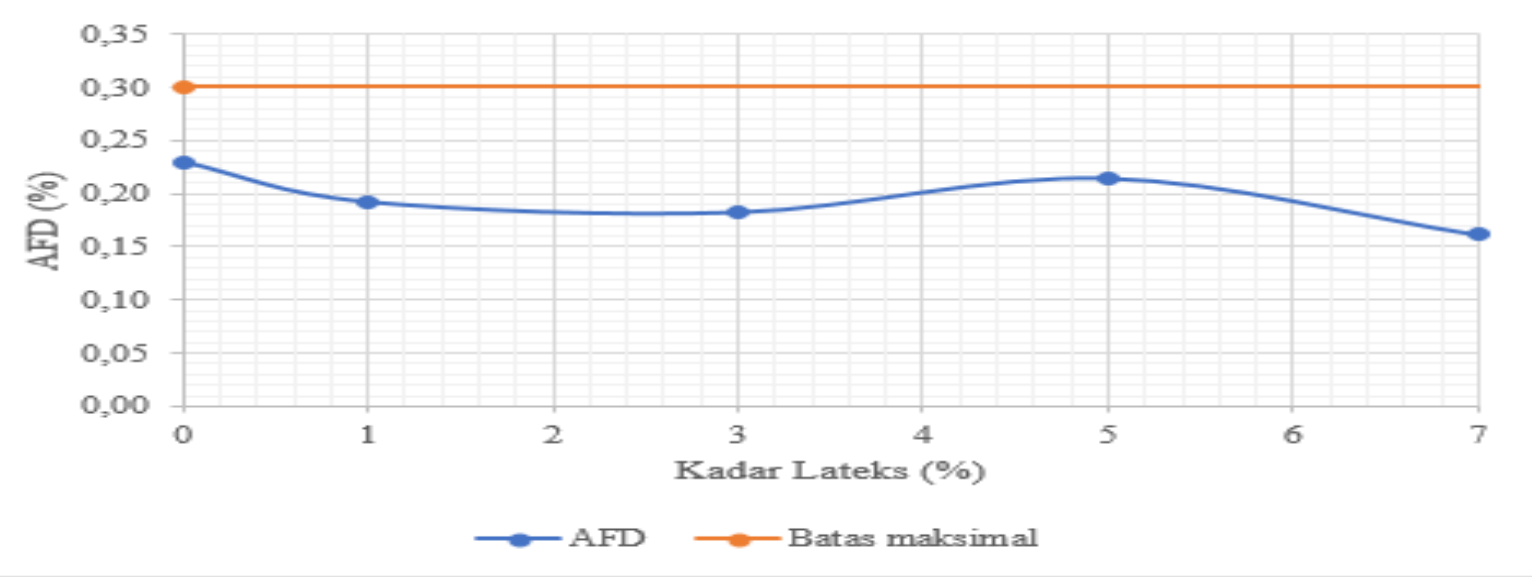

GAMBAR 13. Grafik Hubungan Antara Kadar Lateks dan AFD

Pada Gambar 13 dapat dilihat bahwa nilai AFD mengalami penurunan pada kadar lateks $1 \%$ dan $3 \%$, dan meningkat pada kadar lateks $5 \%$, lalu turun kembali pada kadar lateks $7 \%$. Hal ini menunjukkan bahwa penambahan kadar lateks cenderung menurunkan nilai AFD.

Pada Gambar 14 dapat dilihat bahwa nilai CL kecenderungan mengalami kenaikan dengan bertambahnya kadar lateks, tetapi masih dibawah batas maksimal nilai CL yang disyaratkan oleh AAPA (1997).

\section{Kadar Lateks Optimum}

Hasil pembahasan dari Gambar 9 sampai Gambar 14 diplotkan ke dalam grafik pita seperti saat mencari nilai KAO untuk menentukan nilai kadar lateks optimum (KLO). Hasil kadar lateks optimum dapat dilihat pada Tabel 11 .

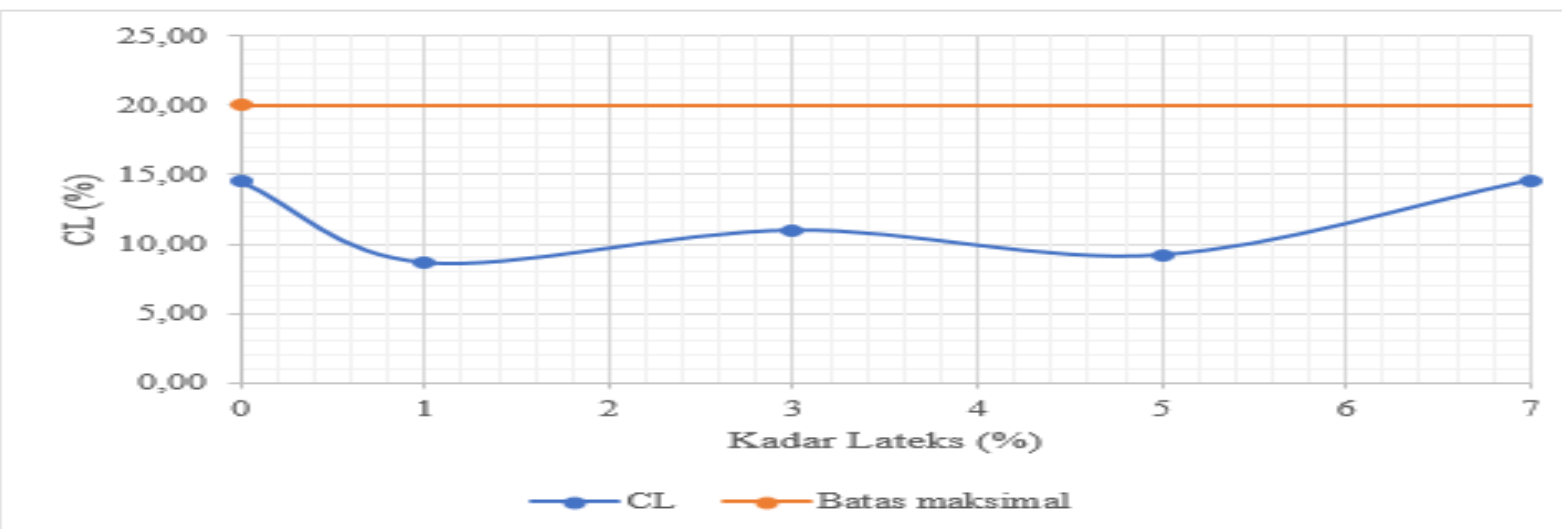

GAMBAR 14. Grafik Hubungan Antara Kadar Lateks dan CL

TABEL 11. Hasil Kadar Lateks Optimum

\begin{tabular}{l|l|l|l|}
\hline & \multicolumn{3}{c}{ Kadar Lateks (\%) } \\
\cline { 2 - 4 } Karakteristik Campuran & & $\mathbf{3}$ & $\mathbf{5}$ \\
\hline CL (\%) & & & \\
AFD (\%) & & & \\
\cline { 2 - 4 } Stabilitas (kg) & & & \\
Flow (mm) & & & \\
VIM (\%) & & & \\
MQ (kg/mm) & & & \\
\hline Kadar Lateks Optimum : 7 \% & & & \\
\hline
\end{tabular}


Dari Tabel 11 dapat dilihat bahwa kadar lateks optimum adalah $7 \%$. Nilai lateks optimum pada kadar $7 \%$ bisa tetap digunakan walaupun hasil nilai penetrasi kurang dari standar aspal murni. Hal ini disebutkan juga pada peraturan terkait dengan spesifikasi campuran aspal, bahwa untuk aspal modifikasi tetap bisa digunakan selama hasil pengujian campuran aspal modifikasi sesuai dengan spesifikasi.

\section{KESIMPULAN}

Berdasarkan hasil penelitian yang telah dilakukan, dapat disimpulkan bahwa, pada pengujian aspal dengan campuran lateks didapat nilai penetrasi tertinggi adalah 63,9, kehilangan berat minyak 0,2576 , nilai daktalitas, titik lembek mengalami kenaikan seiring penambahan kadar lateks. Didapatkan nilai KAO adalah $5,75 \%$ dari total berat campuran. Pada pengujian aspal porus dengan variasi kadar lateks didapat nilai flow dan VIM cenderung mengalami peningkatan seiring bertambahnya kadar lateks, nilai stabilitas marshall tertinggi $592,04 \mathrm{~kg}$, nilai marshall quotient $132,76 \mathrm{~kg} / \mathrm{mm}$, nilai asphalt flow down $0,21 \%$ dan nilai cantabro loss adalah $14,61 \%$.

\section{DAFTAR PUSTAKA}

Amiruddin, Ibrahim, Sulianti, I., \& Subrianto, A. (2018). Pemanfaatan material lokal dalam pembuatan aspal porus tipe ACWC yang aman dan ramah lingkungan. Jurnal Forum Mekanika, 7(2), 59-67. https://doi.org/10.33322/forummekanika. v7i2.199

Arifin, M. Z., Bowoputro, H., dan Falih, N. R. (2018). Pengaruh variasi kadar dan panjang serabut kelapa terhadap karakteristik Marshall pada aspal porus. Jurnal Mahasiswa Jurusan Teknik Sipil, 1(2), 760-769.

Fauziah, M., \& Wijayati, F. S. (2016). Pengaruh kadar limbah kaca sebagai substitusi agregat halus terhadap karakteristik campuran aspal porus. Teknisia, 21(2), 261-273.

Ismayalomi, S., Rahardjo, B., \& Pranoto, P. (2019). Kajian eksperimental penambahan plastik PET (Polyethylene
Terephtalate) dan asbuton LGA (Lawele Granular Asphalt) pada campuran aspal porus. Bangunan, 24(1), 1-14. http://dx.doi.org/10.17977/um071v24i12 $019 \mathrm{p} \% 25 \mathrm{p}$

Ma, Y., Chen, X., Geng, Y., \& Zhang, X. (2020). Effect of clogging on the permeability of porous asphalt pavement, Advances in Materials Science and Engineering, 1-9. https://doi.org/10.1155/2020/4851291

Ghulam, M., Nariswari, W., Ariyanto, E., \& Gunawan, T. (2017). Nilai stabilitas porous asphalt menggunakan material lokal. Potensi: Jurnal Sipil Politeknik, 19(1).

https://doi.org/10.35313/potensi.v19i1.5 31

Nursandah, F., \& Zaenuri, M. (2019). Penelitian penambahan karet alam (lateks) pada campuran laston AC-WC terhadap karakteristik Marshall. CIVILLA: Jurnal Teknik Sipil Universitas Islam Lamongan, 4(2), 262267. https://doi.org/10.30736/cvl.v4i2.375

Padilha Thives, L., Ghisi, E., Gherardt Brecht, D., \& Menegasso Pires, D. (2018). Filtering Capability of Porous Asphalt Pavements, Water, 10(2), 1-17. https://doi.org/10.3390/w10020206

Suaryana, N., \& Sofyan, T. S. (2019). Performance evaluation of hot mixture asphalt using concentrated rubber latex, rubber compound and synthetic polymer as modifier. Civil Engineering Dimension, 21(1), 36-42. https://doi.org/10.9744/ced.21.1.36-42

Thanaya, I. N. A., Puranto, I. G. R., \& Nugraha, I. N. S. (2015). Studi karakteristik campuran aspal beton lapis aus (AC-WC) menggunakan aspal penetrasi 60/70 dengan penambahan lateks. Media Komunikasi Teknik Sipil, 22(2), 77-86.

PENULIS:

\section{Anita Rahmawati}

Program Studi Teknik Sipil, Fakultas Teknik, Universitas Muhammadiyah Yogyakarta. Jalan Brawijaya, Tamantirto, Kasihan, Bantul. 
Email: anita.rahmawati@umy.ac.id

\section{Ridwan Nur Hidayat}

Program Studi Teknik Sipil, Fakultas Teknik, Universitas Muhammadiyah Yogyakarta. Jalan Brawijaya, Tamantirto, Kasihan, Bantul.

Email: ridwan.nur.2016@ft.umy.ac.id 